\title{
Evaluation of the Scenarios of Facilities Maintenance Management of Sport Complexes in South West Nigeria
}

\author{
Olufemi E. Akinsola \\ Department Of Building Technology, Yaba College Of Technology, Lagos, Nigeria \\ E-mail: akinsolaolufemi@yahoo.co.uk \\ Julius Ayo Fapohunda (Corresponding author) \\ Cape Peninsula University of Technology, Department of the Built Environment \\ Faculty of Engineering, Bellville Campus, Cape Town, South Africa \\ E-mail: fapohundaj@cput.ac.za \\ Olabode E. Ogunsanmi \\ Department of Building, University of Lagos \\ Akoka, Lagos State, Nigeria \\ E-mail: Bode_ogunsanmi2004@yahoo.co.uk \\ Ajibola O Fatokun \\ Department of Building Technology, Yaba College Of Technology, Lagos, Nigeria \\ E-mail: ajibolaoladipo@yahoo.com
}

$\begin{array}{lc}\text { Received: January 28, } 2012 \quad \text { Accepted: March 8, } 2012 \quad \text { Published: April 1, } 2012 \\ \text { doi:10.5539/jsd.v5n4p99 } & \text { URL: http://dx.doi.org/10.5539/jsd.v5n4p99 }\end{array}$

\begin{abstract}
The philosophy of every maintenance practice and operation in any organization is usually to provide a structurally sound and aesthetically appealing environment throughout the life of a property. Maintenance has generally been referred to as all works carried out to keep and restore an item to a currently acceptable standard. This work evaluates the performance of facilities maintenance management in the maintenance of sport complexes in South-West Nigeria. The study research method includes physical observation, administration of questionnaires to measure performance. In order to gather information, structured questionnaires were administer at the study area (the six stadia covered), the management staff, the maintenance staff and the user of the facilities in each of the stadia, covering kiosk owner, sport men and women, spectators, and lover of sports. The study revealed some factors affecting performance in the maintenance of sports complexes among which are: funding, organizational structure, political factors, ownership types, and security. The study concluded that it is only when adequate fund is provided and fully utilized in the maintenance of sport complexes that one will enjoy the initial investment in them and the consequent accruing benefits from the complexes will be achieved. The study recommended among others facts that the government should set aside part of her annual budget to maintenance of the sport complexes so as to ensure their fitness and world class standard at all time which will consequently reduce the operating cost and increase the revenue generating capacity of the stadium.
\end{abstract}

Keywords: Facilities management, Maintenance practice, Property, Sport complex, Stadium

\section{Background to the Study}

Managing and maintaining facilities in a stadium might be expensive and problematic in nature but nevertheless, it is inevitable if investment in such a stadium is not to be lost. Egboluche (2009) commented on the perception in Nigeria and states that the culture of management and maintenance has gone down to the drain and this has affected virtually our social and economic lives. When facilities are not well managed and maintained it might lead to various defect which can likely constitute nuisance and disturbances to the users of such facilities. 
Facilities maintenance management is an important tools needed for effective use of any facility. In other to achieve a maximum satisfaction from the investment in the development of stadium, management and maintenance of such stadium must be provided for before, during and after the completion of the stadium. From what obtained today in Nigeria, there is nothing to write about if one considers the state of all the stadia in the country it will be seen that, despite the huge amount of money invested on the stadia, the stadia are still in worst physical state (Egboluche, 2009).

In 1999 when Nigeria wanted to host under 20 World Cup, the Vice president of Federation International Football Association (FIFA) Jack Warner, who hailed and praised Nigerians for creating Eight wonders of the world because of the speedy rehabilitation and renovation of the stadia that were picked for the event, also condemned the appalling state of the same stadia ten years after during inspection of those facilities for FIFA age grade competition in 2009 (Egboluche, 2009). Many people were of the opinion, that the devastating state of most of these stadia is the consequence of the inability to do what is right by the management or doing it at the wrong time. These stadia at the time constructed for the various events were rated as one of the best in the world and nothing was done regarding the maintenance and managements of the facilities at early stage in life.

Consequently, as time passed by, the stadia become unfit for any training purpose let alone hosting local, state, or national and international competitions. The needs for maintenance always arose when there is any competition to be held in the country, and in effect, the cost of maintaining these stadia would be a huge amount of money since such maintenance works have been abandoned for a long period of time This lackadaisical attitude towards maintenance management of sports complexes in Nigeria, has affected the country image negatively. However, what the Government (Local, State and Federal), has failed to realize is that, when proper and efficient maintenance management are in place it reduces the cost of repairs and net profits which will have substantial positive effect on the operating costs and consequently makes it easier to project future margins and profitability (Thomas, 2007). The poor maintenance management practice in Nigeria, particularly in some regions has resulted to loss of value in investment on those sporting complexes and eventually the cost of restoring the facilities when the need arises in the sporting complexes to their initial state of soundness and good working order is on the high side. It is evident that Nigeria has lost and wasted a large amount of money and time in the development of sports complexes. This is so since investment in terms of money and time in the development of these sports complexes have failed to yield desired result. Visit to some of these stadia revealed devastating state of disrepair. It is the believe of some sports analyst that the poor states of the Nigeria sports arena led to the poor performance of the Nigerian sports men who fail to perform excellently during great competition (Alabi, 2009). This study critically examines the existing physical condition of these stadia and their level of compliances with FIFA benchmarks.

\section{Literature Review}

The word stadium has it origin from the Greek word "stadium" a Greek measure of length roughly 180-200m. The oldest known stadium is the one in Olympia, in western Peloponnese. Greece, where the Olympic Games of Antiquity were held since 776BC. Initially 'the Games' consisted of a single event, a sprint along the length of the Olympia stadium was more or less standardized as a measure of distance (approximately 190 meters or 210yd).

The Practice of standardizing footrace tracks to a length of 180-200 meters (200-220yd) was followed by the Romans thus Greek and Roman stadia have been found in numerous ancient cities (Wikipedia, 2009).

The architectural typology of the modern stadia derives from the classical prototype of the Greek stadia, even if the link between ancient and modern stadia is not always clearly visible. Today's stadia mostly resemble the Greek theatres, and the Roman circuses and Amphitheatres (Rover, 2009). The Greek stadia were the open space where footraces and other athletic contests took place in ancient Greece. The stadia were usually U-shaped, the curve being opposite to the starting point. The courses were generally 600 Greek feet long ( 1 stadia), although the length varied according to local variations of the measuring unit -Natural slopes where used where possible to support the seats (Rover, 2009).

A modern stadium is a place, or venue for sports, concerts or other events, consisting of a field or stage partly or completely surrounded by a structure designed to allow spectators to stand or sit and view the event (Wikipedia, 2009).

It is worthy of note that for about half a century the only event at the ancient Greek Olympic festival was the race that comprised one length of the stadia at Olympia where the word stadium is originally derived from. 
The first stadium to be used in modern times, and the only one to be used during the 19th century, was the excavated and refurbished ancient Panathenaic stadium which has hosted Olympic Games in 1870, 1875, 1896, 1906, and 2004. The excavation and refurbishment of the stadium was part of the legacy of the Greek national benefactor Evangelist Zappas. The Australian organizing committee for the Sydney 2000 Olympic Games incorrectly minted the image of the Colosseum arena of Rome on all the medals to Olympic medal winners. The Colosseum has never hosted Olympic Games awarded.

Facilities management according to the (Centre for Facilities Management, 2010) is the process by which an organization delivers and sustains support services in a quality environment to meet strategic needs". It may also be defined as "the process by which an organization ensures that its buildings, systems and services support core operations and processes as well as contribute to achieving its strategic objectives in changing conditions (Keith, 2009). As buildings become more complex and house more technology, user expectations rise and the pressure on them to perform increases. Increasing legislation to ensure health, safety and welfare as well as to protect the environment has added new responsibilities on companies to manage the workplace. Center for Facilities Management, (CFM, 2010) emphasize the need to focus resources on meeting user needs to support the key role of people in organizations and strives to continuously improve quality, reduce risks and ensure value for money.

CFM (2010), scope of the discipline covers all aspects of property, space, environmental control, health and safety, and support services, and requires that appropriate control points are established in the organization. The facility plan will set out these policies and identifies corporate guideline and standards. The plan will describe the organization, structure, procedures and responsibilities of all stakeholders. Facilities management lay out an organization's response to vital issues such as space allocation and charging, environmental control and protection, direct and contract employment. Facilities management is relevant to all sectors in developed and developed and developing countries".

In the International Facilities Management Association (IFMA, 2009) report, facilities management is described as the integration process which involves the practice of coordinating maintaining and developing all physical, human and material resources of an organization in order to foster improvement in its efficiency and effectiveness towards the achievement of organizational goals and objectives, essentially, it is apparent that the main objectives of facilities management is to ensure that all the equipment and facilities contained in the built environment for effective running of an organization are in their best condition always making it function in such a way that breakdown and/or delay in operation is eliminated as far as possible.

\section{Research Method, Data Analysis and Discussion of Findings}

Quantitative research method which involves the use of questionnaire (multiple choice type) are designed to evaluate the performance of sport complex facilities maintenance management saddled with the responsibility of upkeep of these stadia in Southwest Nigeria. The study areas comprises of selected stadia, which are well known and frequently used for recreational and sport activities in Nigeria, and significantly known to have the same cultural and social background and similar sport culture. The stadia chosen includes; Liberty stadium (Ibadan), Lekan Salami Stadium (Ibadan), Olubadan stadium (Ibadan), Osogbo stadium (Osogbo), Ondo stadium (Ondo), Akure Township stadium (Akure).

A total of 150 questionnaires were administered to professionals as well as operators of the stadia out of which about 135 were refined representing $90 \%$ response: this enables responses to be obtained from respondents with thorough and good knowledge of available facilities in all the stadia. The data so collected were analysed using descriptive statistics and mean item score using Statistical Package for the Social Sciences (SPSS). The data results are ranked accordingly.

Table 1 shows the comparative ratings of the six stadia on timeliness. Akure stadium, Ondo stadium and Olubadan Stadium responded more promptly to medical facilities ranked first, stadium ranked Pitch/Field first, Lekan Salami picked lawn/grass as item of facility that will be more promptly attended to out 43 facilities listed. Liberty Stadium choice was floor slab/cracks, Items ranked between 1-5th and found common to the six stadia are medical facilities, Security, Tracks, Pitch/field, and Power supply. However among the least promptly attended to facilities common to the six stadia and ranked between 38th - 43rd are: Fixtures, Beam and Column cracks, Floor slab cracks, and paint/finishes (internal).

The Table 1 also shows the average ratings of the five stadia on timeliness measure. Liberty stadium has the highest performance with $53 \%$ while Ondo came next with $51 \%$, followed by Osogbo stadium with $47 \%$, while Olubadan and Lekan salami has $43 \%$ respectively and Akure township stadium is the least with $35 \%$ of performance rating. 
The Average Mean on Timeliness Measure (C1) for Akure Stadium, Osogbo Stadium, Ondo Stadium, Lekan Salami Stadium, Liberty Stadium and Olubadan Stadium.

Average Mean on Timeliness measure $=\frac{C 1+C 2+C 3+C 4+C 5+C 6}{6}=2.27$

From Table 2, the facility maintenance and service quality are ranked for the 43 facilities found in a stadia. The facilities ranked between 1-6th and found common to the six stadia are: Tracks, Main bowl, Walls, Fence, Floor Slab/Cracks, Pitch and Field though they had different performance rating within the boundary of 1-6th.The least common ranked facilities in the six stadia are: Shops and Kiosks, Water Supply, Swimming Pool, Structures/Leakages, Ceiling and Roof.

The Performance Rating of the six stadia reflects that Akure Stadium Came first with 92\%, Liberty Stadium 2nd with $89 \%$, Oshogbo 3rd with $86 \%$, Olubadan Stadium came 4th with $83 \%$, Ondo 5th with $80 \%$ while Lekan Salami stadium came a distant 6 th with $78 \%$.

The Average Mean on Facility Maintenance Repair/Service Quality (C2) Akure Stadium, Osogbo Stadium, Ondo Stadium, Lekan Salami Stadium, Liberty Stadium and Olubadan Stadium = 4.24.

Table 3, shows the result of the respondent rating of level of multiplicity of skilled labour in the maintenance organization in the stadia. The stadium with the highest level of multiplicity of skilled labour is Olubadan Stadium with $69 \%$ rating, coming next to it is Ondo Stadium with 68\%, Lekan Salami and Liberty Stadium came 3rd with $67 \%$ while Osogbo Stadium came 4th with $61 \%$ performance rating. The Average Mean on Multiplicity Of Service (C3) Akure Stadium, Osogbo Stadium, Ondo Stadium, Lekan Salami Stadium, Liberty Stadium and Olubadan Stadium $=3.23$.

On effort collaboration factor, Osogbo and Lekan Salami ranked first as shown in Table 4 with $70 \%$, Akure 2nd with $67 \%$, Ondo 3rd with $64 \%$, Liberty Stadium came 4th with $62 \%$ while the least performing stadium with respect to efforts collaboration among the maintenance staff is Olubadan Stadium with $60 \%$. The Average Mean on Efforts Collaboration measure between (C4) Akure Stadium, Osogbo Stadium, Ondo Stadium, Lekan Salami Stadium, Liberty Stadium and Olubadan Stadium $=3.28$.

Regarding the 'cash flow regularity' issue as shown on Table 5, the survey findings reveal that Liberty Stadium is rated first with $80 \%$, Ondo Stadium is 2nd with $77 \%$, Lekan Salami is 3rd with $69 \%$, both Akure and Osogbo Stadia are 4th with $68 \%$, while Olubadan Stadium is the least in ranking with $66 \%$ in cash flow regularity. The Average Mean on Cash Flow Regularity Measure (F1) Akure Stadium, Osogbo Stadium, Ondo Stadium, Lekan Salami Stadium, Liberty Stadium and Olubadan Stadium is equal to 3.55.

On items that contributes to cash flow performance from Table 6, in the stadia studied ,T.V rights, Sales of tickets, Adverts, Restaurants/kiosks, corporate suites and responsibilities ,Sales Souvenirs were the items which contribute more to cash flow performance and were common to the six stadia surveyed. The least supportive items on cash flow rating are medical facilities, Jersey branding, School support, and rents.

On performance ratings, Liberty Stadium came first with 80\%, Ondo Stadium came 2nd with 77\%, Lekan Salami Stadium came 3rd with 69\%, Akure and Osogbo Stadium came 4th with 68\% while Olubadan Stadium came last with 66\%. The Average Mean on Cash Flow Rating (F2) Akure Stadium, Osogbo Stadium, Ondo Stadium, Lekan Salami Stadium, Liberty Stadium and Olubadan Stadium is equal to 2.95.

From Table 7, it can be deduced from the analysed data from the respondent that the capability to cut cost of maintenance in asset management of working capital are rated first, then reduction were achieved in administrative cost, while productivity with cost reduction is rated least. Performance wise, Liberty came first with $85 \%$, next to it is, Osogbo and Ondo Stadium with $83 \%$ each, and coming third is Lekan Salami Stadium with $80 \%$ and Olubadan stadium came 4th with $79.33 \%$ while Akure Stadium came last with $79 \%$. The Average Mean on Facility Maintenance Cost Reduction Measure (F3) Akure Stadium, Osogbo Stadium, Ondo Stadium, Lekan Salami Stadium, Liberty Stadium and Olubadan Stadium is equal to 3.38.

\section{Summary of the Findings and Topical Issues}

Table 8 shows the total performance rating of the six stadia studied. It shows that considering the two perspectives of Financial growth and Business Perspectives, Liberty Stadium came first with $71 \%$ overall rating, Osogbo and Ondo stadium came 2nd with 67\% rating each, Akure and Olubadan stadium came third with 63\% performance rating while Lekan Salami Stadium came last with $62 \%$. The performances of each of the stadium are rated as follows: Liberty Stadium came first with $71 \%$ overall in performance in terms of financial growth and Customers satisfaction. Hence it could be concluded that amongst the six stadia surveyed, Liberty Stadium, 
Ibadan, is the best. This is a Federal Stadium, and often renovations are done on all facets of its facilities. It was one of the stadia of federal government previously identified for privatization. However, the Ministerial Committee Report on Federal stadia recommended that the facilities need to be upgraded before privatization since it appeared that the obsolete facilities at the Liberty Stadium may not be attractive to investors; hence, initiate the current facilities upgrade and renovations. Osogbo and Ondo Stadia are both second with $67 \%$ overall performance ratings. Ondo stadium is currently undergoing renovations and the contractor on site appeared business like with the dispatch with which the works are handled. Osogbo stadium is not undergoing any renovation currently but the appearance of the facilities shows that they are regularly maintained. Akure and Olubadan Stadium came 3rd in performance with $62 \%$ respectively. These two stadia are jointly owned by both Ondo state and Oyo state government: these Stadia are hardly used for major sport activities; they are significantly having problems of poor government subventions and lack of considerable internally generated revenue. Hence, the management of the Akure and Olubadan stadia could fairly maintain most of the occurring facilities problems, to enable the facilities performed to somewhat standard. Lekan Salami stadium is distinctly least with $62 \%$ performance rating: it is a state stadium named after a well renowned sport philanthropist. The Oyo state resources on facility maintenance are economically used for both Olubadan and Lekan Salami stadia, both located in Ibadan, Oyo state. The non regularity of sporting and events in the Oyo and Ondo states may have affected the stadia internal generated revenue and effective maintenance management.

Furthermore, the study also examined the mode of generating fund for effective maintenance operation and in line with this it was discovered that the mode of generating fund at the case study area are through the Federal Government, State Government, rent, and Internal Revenue Generation internally. In the entire six stadia, liberty stadium is ranked first in term of annual budget disbursement, this might have been a result of Federal Government disposition to releasing budgetary allocations to Ministries and Departmental Agencies as at when due in each quarter of the year.

The study concludes that these stadia performance in terms of turnaround time (TAT) for some of the facilities are not good enough. Where efforts were made to focus on medical facilities and disregard is the rule of the day when it comes to roof and ceiling leakages. It is clear that this permissiveness will encourage higher deterioration of many other facilities due to occurrence of rain into the facilities. Repair and turnaround time (time taking to effect repairs). In term of timelines, Liberty Stadium still come first. It is a federal stadium, this imply that federal stadia have more personnel than state stadia hence, earlier response to maintenance problems.

This study reveals some typical issues and factors which will contribute to the effective performance and efficiency of the sport complexes studied in Southwest Nigeria. In addition, this study reveals the performance ratings of the stadia and identifies areas where the stadia are significantly performing well and areas that require considerable improvement. The study identifies, discusses and establishes principal factors that contribute to maintenance problems of sport complexes in Southwest Nigeria:

1) Performance Ratings of sport complexes;

2) Funding of sport complexes;

3) Non-availability of skilful personnel for facility maintenance;

4) Delay in effecting repairs/Timeliness of response.

It is worthy to appreciate that facilities maintenance is highly expensive and require a large amount of investment especially when dealing with a complex structural environment like stadium. Therefore, the role played by fund in maintenance of sport complexes cannot be over-emphasized. Thus, it is only when adequate fund is utilized in the maintenance of sport complexes that one will enjoy the initial investment in the Stadia and the consequent accruing of profit from the complexes will be attained. To Keith (2009), it is not possible due to economical and technical reasons to produce a maintenance free plant with zero risk of failure. Along the same line Akinsola (2009) also asserts that it is impossible to have buildings that are maintenance free. Ikpo and Ighalo (2001) also confirmed the significant of fund when explaining the roles played by finance in the development of sport complexes, states that the development of sport complex facilities involves enormous capital expenditure, which is inevitable due to the intrinsic value of sports and its global acceptability with respect to physical, physiological and mental contributions to the promotion of health. Ikpo (2001) further noted that sport buildings pose a lot of problems to management. Some of these problems are fundamental to public buildings while others are peculiar to recreational facilities; all these argument the fact that finance has major roles in the maintenance of sport complexes. 


\section{Conclusion and Recommendations}

With appropriate reference to the data analysis and findings the following are hereby drawn:

- Adequate and regular inspection of the facilities embedded in the sport complex should be done from time to time so as to arrest any unforeseen circumstances and avoid any major breakdowns.

- Corrective repairs should without any delay be carried out regularly on any identified problem areas during inspection and proper records of same should be kept.

- Adequate workshops and seminars regarding new technological innovation on maintenance programme should be organized from time to time to upgrade the knowledge of the personnel involved in maintenance.

- Management of sport complexes are also advised to embark on the three major maintenance programmed via planned, condition based and corrective maintenance programmed in the maintenance of sport complexes as one out of the three cannot compensate the effectiveness of the other.

- Facilities maintenance management option should be considered in the maintenance of sport complexes and should not be restricted to a particular period or time when there is any sporting even to be held in the sport complexes and when this is adopted it should last long as the sport complexes itself.

- The government is advised to set aside part of her annual budget and disburse same regularly for the maintenance of the sport complexes so as to ensure their fullness' and world class standard at all time.

- The sport complexes should be available to event organizer who may want to rent part of the complex in order to stage their event; this will enhance the internal revenue generating capacity of the stadium and also add to the finances which will eventually cater for maintenance cost. However, this should be under the strict control of the maintenance personnel in order to ensure that no damage is done to the facilities.

- Corporate Naming of Stadium is also encouraged so as to help take the burden of massive expense of building and maintaining a stadium. This is practiced in United State of America and other European countries and it is seen as been effective.

- Adequate tools and equipment should be provided so as to ensure effectiveness and efficiency of maintenance.

The study revealed and established some principal factors that are significantly affecting performance in the maintenance of sports complexes among which are funding, organizational structure, political factors, ownership types, and security. The study concluded that it is only when adequate fund is provided and fully utilized in the maintenance of sport complexes that the stakeholders will enjoy the initial investment in the stadium and the consequent accruing benefits from the complexes will be achieved. The study recommended that the government should set aside part of her annual budget to maintenance of the sport complexes so as to ensure the stadia fitness for purpose and world class standard at all time, which will in consequent reduce the operating cost and increase the revenue generating capacity of the stadia.

\section{References}

Adebayo, S. O. (1991). A Study of the Maintenance Management of Public Building, Unpublished Ph.D. Thesis, Dept. of Building, University of Lagos, Nigeria.

Adenuga, O. A. (1999). Building maintenance in Nigeria; structural deterioration, recognition and diagnosis of causes and remedies. Shelter Watch Lagos, 1 (1), 10 - 25.

Adenuga, O. A. (2008). Evaluation of maintenance management practice of public hospital buildings in South-West Nigeria. Unpublished Ph.D. Thesis, Dept. of Building, University of Lagos, Nigeria.

Akinsola, E. O. (2009). Assessment of the factors influencing maintenance programme of tertiary institutions in South west Nigeria, The Professional Builder. Journal of the Nigerian Institute of Building (pp. 40 - 43).

British Standards Institution. (1984). B.S 3811: Glossary of General Terms Used in Maintenance organization. BS I, London.

Brocka, B., \& Brocka, M. S. (1992). Quality Management: Implementing the Best Ideas of the Masters, management, Blackwell science, London. Care Information Management. 22 (1), 26-29. [Online] Available: www.ojni.org/12_2/bindberg.pdf (July 30, 2010)

Bullinger H. J. (2010). Towards User Centered Design (VCD) in Architecture. Proceedings of 1990 symposium on users Centered Design. [Online] Available: http//www.else vier.com. retrieve /pii/ 50166361509002115 
Celestine, V. (1989). Building Maintenance: a Catalyst of a Economic Development. Journal of the Nigerian Institution of Estate Surveyors and Valuers, 1 (5).

CFM. (2010). The FM Sector and its Status in the Wordic Countries: Report 21. 2010. A research publication of centre for facilities management Realdamia research publisher retrieved from www.cfm, dtu. dk /up load centre / man -cfm / 101001\% report \% Nordic pdf

Chanter, B., \& Swallow, P. (1996). Maintenance organization, Building, Maintenance Management. London: Blackwell Science.

Chartered Institution of Building. (1975). Maintenance Management, Englemere, England.

Egboluche, U. (2009). The Sorry State of Nigeria Stadia, Expository essay in Nigeria Vanguard Newspapers.

Facilities centre.com. (2010). Facilities management terms and definitions. [Online] Available: www.facilitiescentre.com/contract term conditions/index .php. (January $25^{\text {th }}, 2011$ )

IFMA. (2009). Strategic Facility Planning, A white paper on strategic facility planning. [Online] Available: www.ifma .org. /tools / files/ SFP - white paper. pdf. (January $25^{\text {th }}, 2011$ )

Ikpo, I. J., \& Ighalo, J. I. (2001). Parameters for measuring the rate of deterioration of dwellings. Journal of the Nigerian Institution of Estate Surveyors and Valuers, 24 (1), 1-5.

Ikpo, I. J., \& Ighalo, J. I. (2009). Parameters for measuring the rate of deterioration of dwellings. Journal of the Nigeria Institute of Estate Surveyors and Valuers. 24 (1), 1-5.

Keith, E. (2009). Performance based facility management. [Online] Available: www.ijfm.net /index .php /ijfm / article/ view PDF interstitial $/ 11 / 14$ (January $25^{\text {th }}, 2011$ )

Lundberg, C. (2007). Care Facilities. Journal of health care information management, 22 (1), 26-29. [Online] Available: www.ojni.org/12_2/bindberg.pdf (January $25^{\text {th }}, 2011$ )

Rover, T. (2009). [Online] Available: www.footballground guide.ipbhost.com/index.php? Show topic $=18788$

Thomas, S. (2007). Assets reliability and maintenance management. [Online] Available: www.accenture.com $/ \mathrm{N}$ $\mathrm{R} /$ rdonlyres /0559c958-58 EI -456D -98CC - 33C2 885 F7 A96/ O /Accenture /Asset-Reliability Maintenance-Management. pdf (January $\left.25^{\text {th }}, 2011\right)$

Tranmere R. (2009). Aries Amphethtre retrived from www.footballground guide. Ipbhost .com /index. Php? Show topic $=18788\left(\right.$ January $\left.25^{\text {th }}, 2011\right)$

Ubani, T. (2009). U- 17 World Cup: FIFA Condemns Nigeria. [Online] Available: www. Ndn. Nigeria daily news.com /templates $/ \mathrm{a}=17901 \$ \mathrm{z}=50$ (January $28^{\text {th }}, 2011$ )

Wikipedia. (2009). Stadium. [Online] Available: www. Wikipedia .org / wki /stadium (January $25^{\text {th }}, 2011$ )

Table 1. Time lines measure $\left(\mathrm{C}_{1}\right)$

\begin{tabular}{|c|c|c|c|c|c|c|c|c|}
\hline AKURE STADIUM & Mean & Rank & $\begin{array}{l}\text { OSHOGBO } \\
\text { STADIUM }\end{array}$ & Mean & Rank & ONDO STADIUM & Mean & Rank \\
\hline $\begin{array}{l}\text { Medical facility } \\
\text { (Clinic) }\end{array}$ & 3 & 1 & Pitch/Field & 3.4 & 1 & $\begin{array}{l}\text { Medical facility } \\
\text { (Clinic) }\end{array}$ & 3.25 & 1 \\
\hline Security & 2.9 & 2 & Tracks & 3.25 & 2 & Lawn /grass & 3.05 & 2 \\
\hline Tracks & 2.9 & 2 & Main bowl & 3.2 & 3 & Tracks & 3 & 3 \\
\hline Pitch/Field & 2.9 & 2 & Concrete structures & 3.05 & 4 & Pitch/Field & 3 & 3 \\
\hline Lawn /grass & 2.85 & 5 & Lawn /grass & 2.9 & 5 & Power supply & 3 & 3 \\
\hline Fire protection & 2.8 & 6 & Power supply & 2.9 & 5 & $\begin{array}{l}\text { Waste Management } \\
\text { (disposal) }\end{array}$ & 3 & 3 \\
\hline Water supply & 2.8 & 6 & $\begin{array}{l}\text { Medical facility } \\
\text { (Clinic) }\end{array}$ & 2.75 & 7 & Drainage & 2.95 & 7 \\
\hline Power supply & 2.7 & 8 & Doors & 2.7 & 8 & Ventilation & 2.9 & 8 \\
\hline Storage & 2.7 & 8 & Security & 2.7 & 8 & $\begin{array}{c}\text { Sanitary Fittings } \\
\text { Fixtures }\end{array}$ & 2.9 & 8 \\
\hline $\begin{array}{l}\text { WasteManagement } \\
\text { (disposal) }\end{array}$ & 2.6 & 10 & $\begin{array}{l}\text { Waste Management } \\
\text { (disposal) }\end{array}$ & 2.7 & 8 & $\begin{array}{l}\text { Equipments } \\
\text { apparatus }\end{array}$ & 2.9 & 8 \\
\hline $\begin{array}{l}\text { Equipments } \\
\text { apparatus }\end{array}$ & 2.5 & 11 & $\begin{array}{c}\text { Roof } \\
\text { structures/leakages }\end{array}$ & 2.6 & 11 & $\begin{array}{c}\text { Telecommunication } \\
\text { system }\end{array}$ & 2.85 & 11 \\
\hline
\end{tabular}


Table 1. Time lines measure $\left(\mathrm{C}_{1}\right)$ (continued)

\begin{tabular}{|c|c|c|c|c|c|c|c|c|}
\hline AKURE STADIUM & Mean & Rank & $\begin{array}{l}\text { OSHOGBO } \\
\text { STADIUM }\end{array}$ & Mean & Rank & ONDO STADIUM & Mean & Rank \\
\hline Drainage & 2.5 & 11 & Seats & 2.55 & 12 & $\begin{array}{l}\text { Electrical } \\
\text { appliances }\end{array}$ & 2.85 & 11 \\
\hline $\begin{array}{l}\text { Offices/Corporate } \\
\text { suites }\end{array}$ & 2.5 & 11 & $\begin{array}{c}\text { Telecommunication } \\
\text { system }\end{array}$ & 2.5 & 13 & Storage & 2.8 & 13 \\
\hline Landscaping & 2.5 & 11 & $\begin{array}{l}\text { Equipments } \\
\text { apparatus }\end{array}$ & 2.5 & 13 & Walls & 2.8 & 13 \\
\hline $\begin{array}{l}\text { Telecommunication } \\
\text { system }\end{array}$ & 2.5 & 11 & $\begin{array}{l}\text { Sanitary Fittings } \\
\text { Fixtures }\end{array}$ & 2.5 & 13 & Main bowl & 2.8 & 13 \\
\hline $\begin{array}{c}\text { Sanitary Fittings } \\
\text { Fixtures }\end{array}$ & 2.5 & 11 & Floor slabs cracks & 2.4 & 16 & Fence & 2.8 & 13 \\
\hline Main bowl & 2.5 & 11 & Fire protection & 2.4 & 16 & Security & 2.75 & 17 \\
\hline Fence & 2.5 & 11 & $\begin{array}{l}\text { Electrical } \\
\text { appliances }\end{array}$ & 2.4 & 16 & Water supply & 2.7 & 18 \\
\hline Car park & 2.45 & 19 & Water supply & 2.35 & 19 & Electronics & 2.7 & 18 \\
\hline Ventilation & 2.45 & 19 & Ventilation & 2.35 & 19 & Car park & 2.65 & 20 \\
\hline Electrical appliances & 2.45 & 19 & $\begin{array}{l}\text { Beams/Columns } \\
\text { Cracks }\end{array}$ & 2.35 & 19 & $\begin{array}{l}\text { Mechanical } \\
\text { appliances }\end{array}$ & 2.55 & 21 \\
\hline Walls & 2.45 & 19 & Drainage & 2.3 & 22 & Swimming pool & 2.55 & 21 \\
\hline Gymnasium & 2.4 & 23 & Gates & 2.3 & 22 & $\begin{array}{l}\text { Offices/Corporate } \\
\text { suites }\end{array}$ & 2.55 & 21 \\
\hline Electronics & 2.35 & 24 & Landscaping & 2.25 & 24 & Fire protection & 2.5 & 24 \\
\hline Indoor games hall & 2.35 & 24 & $\begin{array}{l}\text { Mechanical } \\
\text { appliances }\end{array}$ & 2.25 & 24 & Doors & 2.5 & 24 \\
\hline Swimming pool & 2.3 & 26 & Electronics & 2.25 & 24 & $\begin{array}{c}\text { Roof } \\
\text { structures/leakages }\end{array}$ & 2.5 & 26 \\
\hline Shops/kiosks & 2.3 & 26 & $\begin{array}{l}\text { Offices/Corporate } \\
\text { suites }\end{array}$ & 2.2 & 27 & Gymnasium & 2.45 & 27 \\
\hline $\begin{array}{l}\text { Mechanical } \\
\text { appliances }\end{array}$ & 2.3 & 26 & Swimming pool & 2.2 & 27 & Indoor games hall & 2.45 & 27 \\
\hline Doors & 2.25 & 29 & Car park & 2.2 & 27 & Concrete structures & 2.45 & 27 \\
\hline $\begin{array}{c}\text { Roof } \\
\text { structures/leakages }\end{array}$ & 2.2 & 30 & Gymnasium & 2.15 & 30 & Ceiling & 2.4 & 30 \\
\hline Ceiling & 2.15 & 31 & Indoor games hall & 2.15 & 30 & Windows & 2.3 & 31 \\
\hline Concrete structures & 2.15 & 31 & Shops/kiosks & 2 & 32 & Furniture's & 2.25 & 32 \\
\hline Windows & 2.1 & 33 & Fence & 2 & 32 & Shops/kiosks & 2.2 & 33 \\
\hline Gates & 2.05 & 34 & Walls & 1.95 & 34 & Gates & 2.2 & 33 \\
\hline Furniture's & 2.05 & 34 & $\begin{array}{l}\text { Railings and } \\
\text { Balusters }\end{array}$ & 1.8 & 35 & Fixtures & 2.15 & 35 \\
\hline Seats & 1.95 & 36 & Ceiling & 1.8 & 35 & Landscaping & 2.1 & 36 \\
\hline $\begin{array}{l}\text { Railings ana } \\
\text { Balusters }\end{array}$ & 1.95 & 36 & Windows & 1.75 & 37 & $\begin{array}{l}\text { Railings and } \\
\text { Balusters }\end{array}$ & 2.1 & 36 \\
\hline Fixtures & 1.95 & 36 & Furniture's & 1.7 & 38 & Seats & 2.1 & 36 \\
\hline $\begin{array}{l}\text { Beams/Columns } \\
\text { Cracks }\end{array}$ & 1.95 & 36 & Fixtures & 1.6 & 39 & Floor finishes & 2.05 & 39 \\
\hline Floor slabs cracks & 1.9 & 40 & Floor finishes & 1.5 & 40 & $\begin{array}{l}\text { Beams/Columns } \\
\text { Cracks }\end{array}$ & 1.95 & 40 \\
\hline $\begin{array}{l}\text { Paints/Finishes } \\
\text { (Internal) }\end{array}$ & 1.9 & 40 & $\begin{array}{l}\text { Paints/Finishes } \\
\text { (External) }\end{array}$ & 1.45 & 41 & $\begin{array}{l}\text { Paints/Finishes } \\
\text { (Internal) }\end{array}$ & 1.9 & 41 \\
\hline Floor finishes & 1.85 & 42 & $\begin{array}{l}\text { Paints/Finishes } \\
\text { (Internal) }\end{array}$ & 1.45 & 41 & Floor slabs cracks & 1.85 & 42 \\
\hline $\begin{array}{l}\text { Paints/Finishes } \\
\text { (External) }\end{array}$ & 1.75 & 43 & Pitch/Field & 3.4 & 43 & $\begin{array}{l}\text { Paints/Finishes } \\
\text { (External) }\end{array}$ & 1.8 & 43 \\
\hline TOTAL SCORE & 75.05 & & TOTAL SCORE & 101.1 & & TOTAL SCORE & 109.5 & \\
\hline $\begin{array}{l}\text { TOTAL MEAN } \\
\text { SCORE }\end{array}$ & 1.75 & & $\begin{array}{l}\text { TOTAL MEAN } \\
\text { SCORE }\end{array}$ & 2.35 & & $\begin{array}{l}\text { TOTAL MEAN } \\
\text { SCORE }\end{array}$ & 2.55 & \\
\hline$\%$ PERFORMANCE & 35 & & $\begin{array}{c}\% \\
\text { PERFORMANCE }\end{array}$ & 47 & & $\begin{array}{c}\% \\
\text { PERFORMANCE }\end{array}$ & 51 & \\
\hline
\end{tabular}


Table 1. Timeliness measure $\left(\mathrm{C}_{1}\right)$ (continued)

\begin{tabular}{|c|c|c|c|c|c|c|c|c|}
\hline $\begin{array}{c}\text { LEKAN SALAMI } \\
\text { STADIUM } \\
\end{array}$ & Mean & Rank & $\begin{array}{l}\text { LIBERTY } \\
\text { STADIUM } \\
\end{array}$ & Mean & Rank & $\begin{array}{l}\text { OLUBADAN } \\
\text { STADIUM } \\
\end{array}$ & Mean & Rank \\
\hline Lawn /grass & 2.9 & 1 & $\begin{array}{c}\text { Floor slabs } \\
\text { Cracks }\end{array}$ & 3.4 & 1 & $\begin{array}{l}\text { Medical facility } \\
\text { (Clinic) }\end{array}$ & 2.7 & 1 \\
\hline Medical facility (Clinic) & 2.8 & 2 & $\begin{array}{l}\text { Roof structures } \\
\quad \text { /leakages }\end{array}$ & 3.35 & 2 & $\begin{array}{l}\text { Floor slabs } \\
\text { Cracks }\end{array}$ & 2.7 & 1 \\
\hline Security & 2.65 & 3 & $\begin{array}{l}\text { Medical facility } \\
\text { (Clinic) }\end{array}$ & 3.3 & 3 & Lawn /grass & 2.65 & 3 \\
\hline Storage & 2.6 & 4 & Fire protection & 3.25 & 4 & Storage & 2.6 & 4 \\
\hline Tracks & 2.5 & 5 & Security & 3.2 & 5 & $\begin{array}{l}\text { Beams/Columns } \\
\text { Cracks }\end{array}$ & 2.6 & 4 \\
\hline Pitch/Field & 2.5 & 5 & Water supply & 3.2 & 5 & Power supply & 2.5 & 6 \\
\hline $\begin{array}{c}\text { Waste } \\
\text { Management (disposal) }\end{array}$ & 2.5 & 5 & Main bowl & 3 & 7 & Water supply & 2.45 & 7 \\
\hline Water supply & 2.4 & 8 & Fence & 3 & 7 & Shops/kiosks & 2.4 & 8 \\
\hline Fire protection & 2.4 & 8 & Lawn /grass & 2.95 & 9 & $\begin{array}{l}\text { Waste Management } \\
\text { (disposal) }\end{array}$ & 2.4 & 8 \\
\hline Sanitary Fittings Fixtures & 2.4 & 8 & Seats & 2.95 & 9 & Security & 2.35 & 10 \\
\hline Power supply & 2.35 & 11 & Walls & 2.9 & 10 & $\begin{array}{c}\text { Telecommunication } \\
\text { System }\end{array}$ & 2.35 & 10 \\
\hline Drainage & 2.35 & 11 & $\begin{array}{c}\text { Telecommunication } \\
\text { On system }\end{array}$ & 2.9 & 10 & Gymnasium & 2.35 & 10 \\
\hline Electrical appliances & 2.35 & 11 & Pitch/Field & 2.85 & 13 & Car park & 2.3 & 13 \\
\hline Landscaping & 2.3 & 14 & Storage & 2.85 & 13 & $\begin{array}{l}\text { Equipments } \\
\text { apparatus }\end{array}$ & 2.3 & 13 \\
\hline Ventilation & 2.3 & 14 & Power supply & 2.85 & 13 & $\begin{array}{l}\text { Offices/Corporate } \\
\text { suites }\end{array}$ & 2.3 & 13 \\
\hline Offices/Corporate suites & 2.3 & 14 & Drainage & 2.85 & 13 & $\begin{array}{l}\text { Sanitary Fittings } \\
\text { Fixtures }\end{array}$ & 2.3 & 13 \\
\hline Gymnasium & 2.25 & 17 & $\begin{array}{c}\text { Waste Management } \\
\text { (disposal) }\end{array}$ & 2.75 & 17 & Indoor games hall & 2.25 & 17 \\
\hline Swimming pool & 2.25 & 17 & Landscaping & 2.7 & 18 & Drainage & 2.25 & 17 \\
\hline Car park & 2.25 & 17 & Tracks & 2.65 & 19 & $\begin{array}{l}\text { Electrical } \\
\text { appliances }\end{array}$ & 2.25 & 17 \\
\hline Electronics & 2.25 & 17 & Concrete structures & 2.65 & 19 & Pitch/Field & 2.2 & 20 \\
\hline Shops/kiosks & 2.2 & 21 & Car park & 2.65 & 19 & Swimming pool & 2.2 & 20 \\
\hline Indoor games hall & 2.2 & 21 & $\begin{array}{c}\text { Offices/Corporate } \\
\text { suites }\end{array}$ & 2.65 & 19 & Tracks & 2.15 & 22 \\
\hline Mechanical appliances & 2.2 & 21 & Ventilation & 2.65 & 19 & Main bowl & 2.15 & 22 \\
\hline Equipments apparatus & 2.15 & 24 & $\begin{array}{l}\text { Equipments } \\
\text { apparatus }\end{array}$ & 2.65 & 19 & Walls & 2.15 & 22 \\
\hline $\begin{array}{l}\text { Telecommunication } \\
\text { system }\end{array}$ & 2.1 & 25 & $\begin{array}{c}\text { Sanitary Fittings } \\
\text { Fixtures }\end{array}$ & 2.65 & 19 & Fence & 2.15 & 22 \\
\hline Main bowl & 2.05 & 26 & $\begin{array}{l}\text { Electrical } \\
\text { appliances }\end{array}$ & 2.6 & 26 & Electronics & 2.15 & 22 \\
\hline Fence & 2.05 & 26 & Gymnasium & 2.55 & 27 & $\begin{array}{c}\text { Roof } \\
\text { structures/leakages }\end{array}$ & 2.1 & 27 \\
\hline Doors & 2.05 & 26 & Indoor games hall & 2.5 & 28 & $\begin{array}{l}\text { Mechanical } \\
\text { appliances }\end{array}$ & 2.1 & 27 \\
\hline Walls & 2 & 29 & Ceiling & 2.5 & 28 & Ventilation & 2.05 & 29 \\
\hline Railings and Balusters & 1.95 & 30 & Doors & 2.5 & 28 & Doors & 2 & 30 \\
\hline Ceiling & 1.85 & 31 & Electronics & 2.5 & 28 & Landscaping & 1.95 & 31 \\
\hline Roof structures/leakages & 1.8 & 32 & $\begin{array}{l}\text { Mechanical } \\
\text { appliances }\end{array}$ & 2.45 & 32 & Fire protection & 1.95 & 31 \\
\hline
\end{tabular}


Table 1. Timeliness measure $\left(\mathrm{C}_{1}\right)$ (continued)

\begin{tabular}{|c|c|c|c|c|c|c|c|c|}
\hline $\begin{array}{c}\text { LEKAN SALAMI } \\
\text { STADIUM }\end{array}$ & Mean & Rank & $\begin{array}{l}\text { LIBERTY } \\
\text { STADIUM } \\
\end{array}$ & Mean & Rank & $\begin{array}{l}\text { OLUBADAN } \\
\text { STADIUM }\end{array}$ & Mean & Rank \\
\hline Windows & 1.8 & 32 & Windows & 2.4 & 33 & Ceiling & 1.9 & 33 \\
\hline Furniture's & 1.75 & 34 & Gates & 2.35 & 34 & Windows & 1.9 & 33 \\
\hline Beams/Columns Cracks & 1.75 & 34 & Swimming pool & 2.35 & 34 & Gates & 1.9 & 33 \\
\hline Floor slabs cracks & 1.7 & 36 & $\begin{array}{l}\text { Beams/Columns } \\
\text { Cracks }\end{array}$ & 2.35 & 34 & $\begin{array}{l}\text { Railings and } \\
\text { Balusters }\end{array}$ & 1.85 & 36 \\
\hline Concrete structures & 1.7 & 36 & Shops/kiosks & 2.3 & 37 & Furniture's & 1.85 & 36 \\
\hline Gates & 1.7 & 36 & Furniture's & 2.3 & 37 & $\begin{array}{l}\text { Paints/Finishes } \\
\text { (Internal) }\end{array}$ & 1.85 & 36 \\
\hline Seats & 1.65 & 39 & Fixtures & 2.2 & 39 & Concrete structures & 1.8 & 39 \\
\hline Fixtures & 1.65 & 39 & $\begin{array}{l}\text { Paints/Finishes } \\
\text { (Internal) }\end{array}$ & 2.15 & 40 & Seats & 1.75 & 40 \\
\hline Paints/Finishes(External) & 1.55 & 41 & Floor finishes & 2.1 & 41 & Fixtures & 1.75 & 40 \\
\hline Paints/Finishes (Internal) & 1.55 & 41 & $\begin{array}{l}\text { Railings and } \\
\text { Balusters }\end{array}$ & 2 & 42 & $\begin{array}{l}\text { Paints/Finishes } \\
\text { (External) }\end{array}$ & 1.65 & 42 \\
\hline Floor finishes & 1.55 & 41 & $\begin{array}{l}\text { Paints/Finishes } \\
\text { (External) }\end{array}$ & 1.95 & 43 & Floor finishes & 1.65 & 42 \\
\hline TOTAL SCORE & 91.55 & & TOTAL SCORE & 114.85 & & TOTAL SCORE & 93.15 & \\
\hline TOTAL MEAN SCORE & 2.13 & & $\begin{array}{l}\text { TOTAL MEAN } \\
\text { SCORE }\end{array}$ & 2.67 & & $\begin{array}{l}\text { TOTAL MEAN } \\
\text { SCORE }\end{array}$ & 2.17 & \\
\hline$\%$ PERFORMANCE & 43 & & $\begin{array}{c}\% \\
\text { PERFORMANCE }\end{array}$ & 53 & & $\begin{array}{c}\% \\
\text { PERFORMANCE }\end{array}$ & 43 & \\
\hline
\end{tabular}

Table 2 . Facility maintenance repair/service quality $\left(C_{2}\right)$

\begin{tabular}{|c|c|c|c|c|c|c|c|c|}
\hline AKURE STADIUM & Mean & Rank & $\begin{array}{l}\text { OSHOGBO } \\
\text { STADIUM }\end{array}$ & Mean & Rank & ONDO STADIUM & Mean & Rank \\
\hline Doors & 4.85 & 1 & Tracks & 4.8 & 1 & Tracks & 4.55 & 1 \\
\hline $\begin{array}{c}\text { Beams/Columns } \\
\text { Cracks }\end{array}$ & 4.85 & 1 & Main bowl & 4.75 & 2 & Main bowl & 4.4 & 2 \\
\hline Floor slabs cracks & 4.85 & 1 & Walls & 4.7 & 3 & Walls & 4.35 & 3 \\
\hline Seats & 4.85 & 1 & Fence & 4.7 & 3 & Fence & 4.35 & 3 \\
\hline Tracks & 4.85 & 1 & Floor slabs cracks & 4.6 & 5 & Floor slabs cracks & 4.25 & 5 \\
\hline Pitch/Field & 4.85 & 1 & Pitch/Field & 4.6 & 5 & Pitch/Field & 4.25 & 5 \\
\hline Main bowl & 4.85 & 1 & Concrete structures & 4.6 & 5 & Concrete structures & 4.25 & 5 \\
\hline Concrete structures & 4.85 & 1 & $\begin{array}{c}\text { Roof } \\
\text { structures/leakages }\end{array}$ & 4.55 & 8 & $\begin{array}{c}\text { Roof } \\
\text { structures/leakages }\end{array}$ & 4.2 & 8 \\
\hline Walls & 4.85 & 1 & $\begin{array}{c}\text { Beams/Columns } \\
\text { Cracks }\end{array}$ & 4.45 & 9 & $\begin{array}{c}\text { Beams/Columns } \\
\text { Cracks }\end{array}$ & 4.1 & 9 \\
\hline Fence & 4.85 & 1 & Seats & 4.45 & 9 & Seats & 4.1 & 9 \\
\hline Ceiling & 4.75 & 11 & $\begin{array}{l}\text { Medical facility } \\
\text { (Clinic) }\end{array}$ & 4.4 & 11 & $\begin{array}{l}\text { Medical facility } \\
\quad \text { (Clinic) }\end{array}$ & 4.05 & 11 \\
\hline Windows & 4.75 & 11 & Ventilation & 4.4 & 11 & Ventilation & 4.05 & 11 \\
\hline Gates & 4.75 & 11 & Doors & 4.4 & 11 & Fire protection & 4 & 13 \\
\hline $\begin{array}{c}\text { Roof } \\
\text { structures/leakages }\end{array}$ & 4.75 & 11 & Fire protection & 4.35 & 14 & $\begin{array}{l}\text { Equipments } \\
\text { apparatus }\end{array}$ & 4 & 13 \\
\hline $\begin{array}{c}\text { Medical } \\
\text { facility(Clinic) }\end{array}$ & 4.7 & 15 & $\begin{array}{l}\text { Equipments } \\
\text { apparatus }\end{array}$ & 4.35 & 14 & Gates & 4 & 13 \\
\hline Floor finishes & 4.65 & 16 & Gates & 4.35 & 14 & Doors & 3.95 & 16 \\
\hline Drainage & 4.65 & 16 & Landscaping & 4.3 & 17 & Landscaping & 3.95 & 16 \\
\hline $\begin{array}{l}\text { Paints/Finishes } \\
\text { (External) }\end{array}$ & 4.65 & 16 & Security & 4.3 & 17 & Security & 3.95 & 16 \\
\hline $\begin{array}{l}\text { Paints/Finishes } \\
\text { (Internal) }\end{array}$ & 4.65 & 16 & Power supply & 4.3 & 17 & Power supply & 3.95 & 16 \\
\hline Furnitures & 4.6 & 20 & $\begin{array}{l}\text { Railings and } \\
\text { Balusters }\end{array}$ & 4.3 & 17 & $\begin{array}{l}\text { Railings and } \\
\text { Balusters }\end{array}$ & 3.95 & 16 \\
\hline
\end{tabular}


Table 2. Facility maintenance repair/service quality $\left(\mathrm{C}_{2}\right)$ (Continued)

\begin{tabular}{|c|c|c|c|c|c|c|c|c|}
\hline AKURE STADIUM & Mean & Rank & $\begin{array}{l}\text { OSHOGBO } \\
\text { STADIUM }\end{array}$ & Mean & Rank & ONDO STADIUM & Mean & Rank \\
\hline Power supply & 4.6 & 20 & $\begin{array}{l}\text { Mechanical } \\
\text { Appliances }\end{array}$ & 4.3 & 17 & $\begin{array}{l}\text { Mechanical } \\
\text { appliances }\end{array}$ & 3.95 & 16 \\
\hline Fire protection & 4.55 & 22 & Ceiling & 4.3 & 17 & Ceiling & 3.95 & 16 \\
\hline Ventilation & 4.55 & 22 & Windows & 4.3 & 17 & Windows & 3.95 & 16 \\
\hline $\begin{array}{l}\text { Equipments } \\
\text { apparatus }\end{array}$ & 4.55 & 22 & Drainage & 4.25 & 24 & Storage & 3.9 & 24 \\
\hline $\begin{array}{l}\text { Railings and } \\
\text { Balusters }\end{array}$ & 4.55 & 22 & Storage & 4.25 & 24 & Lawn /grass & 3.9 & 24 \\
\hline Storage & 4.5 & 26 & Lawn /grass & 4.25 & 24 & Car park & 3.9 & 24 \\
\hline Landscaping & 4.5 & 26 & Car park & 4.25 & 24 & $\begin{array}{l}\text { Offices/Corporate } \\
\text { suites. Ites }\end{array}$ & 3.9 & 24 \\
\hline Security & 4.5 & 26 & $\begin{array}{l}\text { Offices/Corporate } \\
\text { suites }\end{array}$ & 4.25 & 24 & $\begin{array}{l}\text { Telecommunication } \\
\text { System }\end{array}$ & 3.9 & 24 \\
\hline $\begin{array}{l}\text { Mechanical } \\
\text { appliances }\end{array}$ & 4.5 & 26 & $\begin{array}{l}\text { Telecommunication } \\
\text { System }\end{array}$ & 4.25 & 24 & Electronics & 3.9 & 24 \\
\hline Lawn /grass & 4.45 & 30 & Electronics & 4.25 & 24 & $\begin{array}{l}\text { Waste Management } \\
\text { (disposal) }\end{array}$ & 3.9 & 24 \\
\hline Swimming pool & 4.45 & 30 & $\begin{array}{l}\text { Waste Management } \\
\text { (disposal) }\end{array}$ & 4.25 & 24 & Drainage & 3.9 & 24 \\
\hline Car park & 4.45 & 30 & Floor finishes & 4.2 & 32 & Gymnasium & 3.85 & 32 \\
\hline $\begin{array}{l}\text { Offices/Corporate } \\
\text { suites }\end{array}$ & 4.45 & 30 & Gymnasium & 4.2 & 32 & Indoor games hall & 3.85 & 32 \\
\hline $\begin{array}{c}\text { Telecommunication } \\
\text { system }\end{array}$ & 4.45 & 30 & Indoor games hall & 4.2 & 32 & Electrical appliances & 3.85 & 32 \\
\hline Electronics & 4.45 & 30 & Electrical appliances & 4.2 & 32 & Floor finishes & 3.85 & 32 \\
\hline Electrical appliances & 4.45 & 30 & $\begin{array}{l}\text { Sanitary Fittings } \\
\text { Fixtures }\end{array}$ & 4.2 & 32 & $\begin{array}{l}\text { Paints/Finishes } \\
\text { (External) }\end{array}$ & 3.85 & 32 \\
\hline $\begin{array}{l}\text { Sanitary Fittings } \\
\text { Fixtures }\end{array}$ & 4.45 & 30 & Fixtures & 4.2 & 32 & $\begin{array}{l}\text { Paints/Finishes } \\
\text { (Internal) }\end{array}$ & 3.85 & 32 \\
\hline $\begin{array}{l}\text { Waste Management } \\
\text { (disposal) }\end{array}$ & 4.45 & 30 & $\begin{array}{l}\text { Paints/Finishes } \\
\text { (External) }\end{array}$ & 4.2 & 32 & $\begin{array}{c}\text { Sanitary Fittings } \\
\text { Fixtures }\end{array}$ & 3.85 & 32 \\
\hline Fixtures & 4.45 & 30 & $\begin{array}{l}\text { Paints/Finishes } \\
\text { (Internal) }\end{array}$ & 4.2 & 32 & Fixtures & 3.85 & 32 \\
\hline Gymnasium & 4.4 & 40 & Furniture's & 4.15 & 40 & Furniture's & 3.8 & 40 \\
\hline Water supply & 4.4 & 40 & Shops/kiosks & 4.15 & 40 & Shops/kiosks & 3.8 & 40 \\
\hline Indoor games hall & 4.35 & 42 & Swimming pool & 4.1 & 42 & Water supply & 3.75 & 42 \\
\hline Shops/kiosks & 4.3 & 43 & Water supply & 4.1 & 42 & Swimming pool & 3.75 & 42 \\
\hline TOTAL SCORE & 198.15 & & TOTAL SCORE & 186.65 & & TOTAL SCORE & 191.6 & \\
\hline $\begin{array}{l}\text { TOTAL MEAN } \\
\text { SCORE }\end{array}$ & 4.6 & & $\begin{array}{l}\text { TOTAL MEAN } \\
\text { SCORE }\end{array}$ & 4.34 & & $\begin{array}{l}\text { TOTAL MEAN } \\
\text { SCORE }\end{array}$ & 4 & \\
\hline$\%$ PERFORMANCE & 92 & & $\%$ PERFORMANCE & 86 & & $\%$ PERFORMANCE & 80 & \\
\hline
\end{tabular}


Table 2. Facility maintenance repair/servicequality $\left(\mathrm{C}_{2}\right)$ (Continued)

\begin{tabular}{|c|c|c|c|c|c|c|c|c|}
\hline $\begin{array}{l}\text { LEKANSALAMI } \\
\text { STADIUM }\end{array}$ & Mean & Rank & LIBERTY STADIUM & Mean & Rank & $\begin{array}{l}\text { OLUBADAN } \\
\text { STADIUM }\end{array}$ & Mean & Rank \\
\hline Tracks & 4.8 & 1 & Tracks & 4.8 & 1 & $\begin{array}{l}\text { Telecommunication } \\
\text { System }\end{array}$ & 4.8 & 1 \\
\hline Main bowl & 4.75 & 2 & Main bowl & 4.75 & 2 & Tracks & 4.8 & 2 \\
\hline Walls & 4.65 & 3 & $\begin{array}{l}\text { Medical facility } \\
\quad \text { (Clinic) }\end{array}$ & 4.7 & 3 & Power supply & 4.75 & 3 \\
\hline Fence & 4.65 & 3 & Power supply & 4.7 & 3 & Main bowl & 4.75 & 3 \\
\hline Pitch/Field & 4.45 & 5 & Furniture's & 4.7 & 3 & Walls & 4.7 & 5 \\
\hline Concrete structures & 4.45 & 5 & Floor finishes & 4.7 & 3 & Fence & 4.7 & 5 \\
\hline $\begin{array}{l}\text { Medical facility } \\
\quad \text { (Clinic) }\end{array}$ & 4.15 & 7 & Drainage & 4.7 & 3 & Landscaping & 4.6 & 7 \\
\hline Ventilation & 4.15 & 7 & $\begin{array}{l}\text { Paints/Finishes } \\
\text { (Internal) }\end{array}$ & 4.7 & 3 & Ventilation & 4.6 & 7 \\
\hline Doors & 4.1 & 9 & $\begin{array}{l}\text { Paints/Finishes } \\
\quad \text { (Internal) }\end{array}$ & 4.7 & 3 & Floor slabs cracks & 4.6 & 7 \\
\hline Power supply & 4.05 & 10 & Seats & 4.7 & 3 & Pitch/Field & 4.6 & 7 \\
\hline Fire protection & 4 & 11 & Pitch/Field & 4.7 & 3 & Concrete structures & 4.6 & 7 \\
\hline Equipments apparatus & 4 & 11 & Concrete structures & 4.7 & 3 & Water supply & 4.45 & 12 \\
\hline $\begin{array}{l}\text { Railings and } \\
\text { Balusters }\end{array}$ & 4 & 11 & Walls & 4.7 & 3 & Fire protection & 4.45 & 12 \\
\hline Landscaping & 3.95 & 14 & Fence & 4.7 & 3 & Security & 4.45 & 12 \\
\hline Security & 3.95 & 14 & Storage & 4.65 & 15 & $\begin{array}{c}\text { Beams/Columns } \\
\text { Cracks }\end{array}$ & 4.45 & 12 \\
\hline $\begin{array}{l}\text { Mechanical } \\
\text { Appliances }\end{array}$ & 3.95 & 14 & Railings and Balusters & 4.65 & 15 & $\begin{array}{c}\text { Roof structures/leak } \\
\text { ages }\end{array}$ & 4.45 & 12 \\
\hline Gates & 3.95 & 14 & Lawn /grass & 4.6 & 17 & Seats & 4.45 & 12 \\
\hline Storage & 3.9 & 18 & Gymnasium & 4.6 & 17 & Doors & 4.4 & 18 \\
\hline Electronics & 3.85 & 19 & Swimming pool & 4.6 & 17 & $\begin{array}{l}\text { Medical facility } \\
\text { (Clinic) }\end{array}$ & 4.25 & 19 \\
\hline Drainage & 3.85 & 19 & Car park & 4.6 & 17 & Gates & 4.25 & 19 \\
\hline Ceiling & 3.85 & 19 & $\begin{array}{l}\text { Offices/Corporate } \\
\text { Suites }\end{array}$ & 4.6 & 17 & Ceiling & 4.2 & 21 \\
\hline Windows & 3.85 & 19 & Landscaping & 4.6 & 17 & Windows & 4.2 & 21 \\
\hline Lawn /grass & 3.85 & 19 & Fire protection & 4.6 & 17 & Drainage & 4.05 & 23 \\
\hline Car park & 3.85 & 19 & Security & 4.6 & 17 & Floor finishes & 4 & 24 \\
\hline $\begin{array}{l}\text { Offices/Corporate } \\
\text { Suites }\end{array}$ & 3.85 & 19 & $\begin{array}{l}\text { Telecommunication } \\
\text { System }\end{array}$ & 4.6 & 17 & $\begin{array}{l}\text { Paints/Finishes } \\
\text { (External) }\end{array}$ & 4 & 24 \\
\hline $\begin{array}{l}\text { Telecommunication } \\
\text { System }\end{array}$ & 3.85 & 19 & Ventilation & 4.6 & 17 & $\begin{array}{l}\text { Paints/Finishes } \\
\text { (Internal) }\end{array}$ & 4 & 24 \\
\hline $\begin{array}{l}\text { Waste Management } \\
\text { (disposal) }\end{array}$ & 3.85 & 19 & Equipments apparatus & 4.6 & 17 & Equipments apparatus & 3.95 & 27 \\
\hline Gymnasium & 3.75 & 28 & $\begin{array}{l}\text { Mechanical } \\
\text { Appliances }\end{array}$ & 4.6 & 17 & Railings and Balusters & 3.95 & 27 \\
\hline Indoor games hall & 3.75 & 28 & Electronics & 4.6 & 17 & Furniture's & 3.9 & 29 \\
\hline Electrical appliances & 3.75 & 28 & Electrical appliances & 4.6 & 17 & Storage & 3.85 & 30 \\
\hline Floor finishes & 3.75 & 28 & $\begin{array}{l}\text { Sanitary Fittings } \\
\text { Fixtures }\end{array}$ & 4.6 & 17 & $\begin{array}{l}\text { Mechanical } \\
\text { appliances }\end{array}$ & 3.85 & 30 \\
\hline $\begin{array}{l}\text { Paints/Finishes } \\
\text { (External) }\end{array}$ & 3.75 & 28 & $\begin{array}{l}\text { Waste Management } \\
\text { (disposal) }\end{array}$ & 4.6 & 17 & Lawn /grass & 3.75 & 32 \\
\hline $\begin{array}{l}\text { Paints/Finishes } \\
\text { (Internal) }\end{array}$ & 3.75 & 28 & Fixtures & 4.6 & 17 & Car park & 3.75 & 32 \\
\hline $\begin{array}{l}\text { Sanitary Fittings } \\
\text { Fixtures }\end{array}$ & 3.75 & 28 & Water supply & 4.55 & 34 & $\begin{array}{l}\text { Offices/Corporate } \\
\text { Suites }\end{array}$ & 3.75 & 32 \\
\hline Fixtures & 3.75 & 28 & Indoor games hall & 4.5 & 35 & Electronics & 3.75 & 32 \\
\hline Furniture's & 3.7 & 36 & Shops/kiosks & 4.3 & 36 & $\begin{array}{l}\text { Waste Management } \\
\text { (disposal) }\end{array}$ & 3.75 & 32 \\
\hline
\end{tabular}


Table 2. Facility maintenance repair/servicequality $\left(\mathrm{C}_{2}\right)$ (Continued)

\begin{tabular}{|c|c|c|c|c|c|c|c|c|}
\hline $\begin{array}{l}\text { LEKANSALAMI } \\
\text { STADIUM }\end{array}$ & Mean & Rank & LIBERTY STADIUM & Mean & Rank & $\begin{array}{l}\text { OLUBADAN } \\
\text { STADIUM }\end{array}$ & Mean & Rank \\
\hline Shops/kiosks & 3.65 & 37 & Windows & 3.85 & 37 & Electrical appliances & 3.7 & 37 \\
\hline Swimming pool & 3.55 & 38 & Doors & 3.85 & 37 & $\begin{array}{l}\text { Sanitary Fittings } \\
\text { Fixtures }\end{array}$ & 3.7 & 37 \\
\hline Water supply & 3.5 & 39 & Gates & 3.5 & 39 & Fixtures & 3.7 & 37 \\
\hline Floor slabs cracks & 3.2 & 40 & $\begin{array}{c}\text { Roof } \\
\text { structures/leakages }\end{array}$ & 3.5 & 39 & Gymnasium & 3.65 & 40 \\
\hline Seats & 2.95 & 41 & Floor slabs cracks & 3.35 & 41 & Swimming pool & 3.6 & 40 \\
\hline $\begin{array}{l}\text { Beams/Columns } \\
\text { Cracks }\end{array}$ & 2.95 & 41 & $\begin{array}{l}\text { Beams/Columns } \\
\text { Cracks }\end{array}$ & 3.15 & 42 & Indoor games hall & 3.55 & 42 \\
\hline $\begin{array}{c}\text { Roof } \\
\text { structures/leakages }\end{array}$ & 2.85 & 43 & Ceiling & 2.85 & 43 & Shops/kiosks & 3.35 & 43 \\
\hline TOTAL SCORE & 166.9 & & TOTAL SCORE & 190.85 & & TOTAL SCORE & 191.6 & \\
\hline $\begin{array}{l}\text { TOTALMEAN } \\
\text { SCORE }\end{array}$ & 3.89 & & $\begin{array}{l}\text { TOTAL MEAN } \\
\text { SCORE }\end{array}$ & 4.44 & & $\begin{array}{l}\text { TOTAL MEAN } \\
\text { SCORE }\end{array}$ & 4.16 & \\
\hline$\%$ PERFORMANCE & 78 & & $\%$ PERFORMANCE & 89 & & $\%$ PERFORMANCE & 83 & \\
\hline
\end{tabular}

Table 3. Multiplicity of service $\left(\mathrm{C}_{3}\right)$

\begin{tabular}{cccccc}
\hline OSHOGBO & Mean & Rank & ONDO STADIUM & Mean & Rank \\
\hline Maintenance Staff & 3.4 & 1 & Maintenance Staff & 3.9 & 1 \\
Building staff & 3.15 & 2 & Electrical staff & 3.65 & 2 \\
Electrical staff & 3.15 & 2 & Mechanical staff & 3.6 & 3 \\
$\begin{array}{c}\text { Mechanical staff } \\
\text { Refrigerator and Air }\end{array}$ & 3.05 & 4 & Agronomy staff & 3.3 & 4 \\
conditioner & 2.95 & 5 & General cleaner & 3.25 & 5 \\
Agronomy staff & 2.9 & 6 & Building staff & 3.15 & 6 \\
$\begin{array}{c}\text { General cleaner } \\
\text { TOTAL SCORE }\end{array}$ & 2.85 & 7 & $\begin{array}{c}\text { Refrigerator and Air } \\
\text { conditioner }\end{array}$ & 3.15 & 6 \\
TOTAL MEAN & 3.06 & & TOTAL SCORE & 24 & \\
SCORE & 61 & TOTAL MEAN & SCORE & 3.42 & \\
\% PERFORMANCE & PERFORMANCE & 68 & \\
\hline
\end{tabular}

Table 3. Multiplicity of service $\left(\mathrm{C}_{3}\right)$ (continued)

\begin{tabular}{|c|c|c|c|c|c|c|c|c|}
\hline $\begin{array}{l}\text { LEKAN SALAMI } \\
\text { STADIUM }\end{array}$ & Mean & Rank & $\begin{array}{l}\text { LIBERTY } \\
\text { STADIUM }\end{array}$ & Mean & Rank & $\begin{array}{l}\text { OLUBADAN } \\
\text { STADIUM }\end{array}$ & Mean & Rank \\
\hline Building staff & 3.6 & 1 & Maintenance Staff & 3.75 & 1 & Maintenance Staff & 3.9 & 1 \\
\hline Mechanical staff & 3.55 & 2 & Electrical staff & 3.55 & 2 & Electrical staff & 3.65 & 2 \\
\hline Electrical staff & 3.5 & 3 & General cleaner & 3.25 & 3 & Mechanical staff & 3.6 & 3 \\
\hline Agronomy staff & 3.4 & 4 & Building staff & 3.2 & 4 & Agronomy staff & 3.3 & 4 \\
\hline Maintenance Staff & 3.35 & 5 & Mechanical staff & 3.2 & 4 & General cleaner & 3.25 & 5 \\
\hline $\begin{array}{l}\text { Refrigerator and } \\
\text { Air conditioner }\end{array}$ & 3.35 & 5 & Agronomy staff & 3.15 & 6 & Building staff & 3.15 & 6 \\
\hline General cleaner & 2.85 & 7 & $\begin{array}{l}\text { Refrigerator and } \\
\text { Air conditioner }\end{array}$ & 3.1 & 7 & $\begin{array}{l}\text { Refrigerator and Air } \\
\text { conditioner }\end{array}$ & 3.15 & 6 \\
\hline TOTAL SCORE & 23.6 & & TOTAL SCORE & 23.2 & & TOTAL SCORE & 24 & \\
\hline $\begin{array}{l}\text { TOTAL MEAN } \\
\text { SCORE }\end{array}$ & 3.37 & & $\begin{array}{l}\text { TOTAL MEAN } \\
\text { SCORE }\end{array}$ & 3.31 & & $\begin{array}{l}\text { TOTA MEAN } \\
\text { SCORE }\end{array}$ & 3.43 & \\
\hline $\begin{array}{c}\% \\
\text { PERFORMANCE }\end{array}$ & 67 & & $\begin{array}{c}\% \\
\text { PERFORMANCE }\end{array}$ & 67 & & $\begin{array}{c}\% \\
\text { PERFORMANCE }\end{array}$ & 69 & \\
\hline
\end{tabular}


Table 4. Efforts collaboration measure $\left(\mathrm{C}_{4}\right)$

\begin{tabular}{|c|c|c|c|c|c|c|c|c|}
\hline AKURE STADIUM & Mean & Rank & $\begin{array}{l}\text { OSHOGBO } \\
\text { STADIUM }\end{array}$ & Mean & Rank & ONDO STADIUM & Mean & Rank \\
\hline Organization & 3.65 & 1 & Organization & 3.65 & 1 & Organization & 3.4 & 1 \\
\hline Co-ordination & 3.55 & 2 & Co-ordination & 3.6 & 2 & Co-ordination & 3.3 & 2 \\
\hline Communication & 3.25 & 3 & Communication & 3.4 & 3 & Communication & 3.15 & 3 \\
\hline Partnership & 3.25 & 3 & Partnership & 3.4 & 3 & Partnership & 3.15 & 3 \\
\hline Planning & 3.15 & 5 & Planning & 3.35 & 5 & Planning & 3.1 & 5 \\
\hline TOTAL SCORE & 16.85 & & TOTAL SCORE & 17.4 & & TOTAL SCORE & 16.1 & \\
\hline $\begin{array}{l}\text { TOTAL MEAN } \\
\text { SCORE }\end{array}$ & 3.37 & & $\begin{array}{l}\text { TOTAL MEAN } \\
\text { SCORE }\end{array}$ & 3.48 & & $\begin{array}{l}\text { TOTA MEAN } \\
\text { SCORE }\end{array}$ & 3.22 & \\
\hline $\begin{array}{c}\% \\
\text { PERFORMANCE }\end{array}$ & 67 & & $\begin{array}{c}\% \\
\text { PERFORMANCE }\end{array}$ & 70 & & $\begin{array}{c}\% \\
\text { PERFORMANCE }\end{array}$ & 64 & \\
\hline
\end{tabular}

Table 4. Efforts collaboration measure $\left(\mathrm{C}_{4}\right)$ (continued)

\begin{tabular}{|c|c|c|c|c|c|c|c|c|}
\hline $\begin{array}{l}\text { LEKAN SALAMI } \\
\text { STADIUM }\end{array}$ & Mean & Rank & $\begin{array}{l}\text { LIBERTY } \\
\text { STADIUM } \\
\end{array}$ & Mean & Rank & $\begin{array}{c}\text { OLUBADAN } \\
\text { STADIUM }\end{array}$ & Mean & Rank \\
\hline Organization & 3.7 & 1 & Organization & 3.2 & 1 & Planning & 3.15 & 1 \\
\hline Co-ordination & 3.65 & 2 & Co-ordination & 3.15 & 2 & Organization & 3.05 & 2 \\
\hline Communication & 3.4 & 3 & Communication & 3.05 & 3 & Co-ordination & 3.05 & 2 \\
\hline Partnership & 3.4 & 3 & Partnership & 3.05 & 3 & Partnership & 2.85 & 4 \\
\hline Planning & 3.35 & 5 & Planning & 3 & 5 & Communication & 2.8 & 5 \\
\hline TOTAL SCORE & 17.5 & & TOTAL SCORE & 15.45 & & TOTAL SCORE & 14.9 & \\
\hline $\begin{array}{l}\text { TOTAL MEAN } \\
\text { SCORE }\end{array}$ & 3.5 & & $\begin{array}{l}\text { TOTAL MEAN } \\
\text { SCORE }\end{array}$ & 3.09 & & $\begin{array}{l}\text { TOTA MEAN } \\
\text { SCORE }\end{array}$ & 2.99 & \\
\hline $\begin{array}{c}\% \\
\text { PERFORMANCE }\end{array}$ & 70 & & $\begin{array}{c}\% \\
\text { PERFORMANCE }\end{array}$ & 62 & & $\begin{array}{c}\% \\
\text { PERFORMANCE }\end{array}$ & 60 & \\
\hline
\end{tabular}

Table 5. Cash flow regularity measure $\left(\mathrm{F}_{1}\right)$

\begin{tabular}{|c|c|c|c|c|c|c|c|c|}
\hline AKURE STADIUM & Mean & Rank & $\begin{array}{l}\text { OSHOGBO } \\
\text { STADIUM }\end{array}$ & Mean & Rank & ONDO STADIUM & Mean & Rank \\
\hline Sales ticket & 4.1 & 1 & Rent & 4.1 & 1 & T.V rights & 4.5 & 1 \\
\hline Rent & 4 & 2 & T.V rights & 4 & 2 & Rent & 4.5 & 1 \\
\hline School support & 3.9 & 3 & Sales ticket & 4 & 2 & Sales ticket & 4.5 & 1 \\
\hline T.V rights & 3.9 & 3 & $\begin{array}{l}\text { Corporate } \\
\text { responsibility }\end{array}$ & 4 & 2 & School support & 4.4 & 4 \\
\hline $\begin{array}{l}\text { Corporate } \\
\text { responsibility }\end{array}$ & 3.9 & 3 & School support & 3.9 & 5 & $\begin{array}{l}\text { Corporate } \\
\text { responsibility }\end{array}$ & 4.4 & 4 \\
\hline Adverts & 3.8 & 6 & Adverts & 3.8 & 6 & Adverts & 4.3 & 6 \\
\hline $\begin{array}{l}\text { Internal Generated } \\
\text { Revenue (IGR) }\end{array}$ & 3.8 & 6 & $\begin{array}{l}\text { Internal Generated } \\
\text { Revenue (IGR) }\end{array}$ & 3.8 & 7 & $\begin{array}{l}\text { Internal Generated } \\
\text { Revenue (IGR) }\end{array}$ & 4.1 & 7 \\
\hline $\begin{array}{l}\text { Annual budget } \\
\text { Disbursement }\end{array}$ & 3.5 & 8 & $\begin{array}{l}\text { Annual budget } \\
\text { disbursement }\end{array}$ & 3.5 & 8 & $\begin{array}{l}\text { Annual budget } \\
\text { Disbursement }\end{array}$ & 3.9 & 8 \\
\hline Corporate suites & 3.1 & 9 & Corporate suites & 3 & 9 & Corporate suites & 3.5 & 9 \\
\hline Restaurants/kiosks & 2.8 & 10 & Restaurants/kiosks & 2.8 & 10 & Restaurants/kiosks & 3.1 & 10 \\
\hline Sales souvenirs & 2.8 & 10 & Sales souvenirs' & 2.8 & 10 & Sales souvenirs' & 3.1 & 10 \\
\hline Jersey branding & 2.2 & 12 & Jersey branding & 2.2 & 12 & Medical Centers & 2.9 & 12 \\
\hline Medical Centers & 2.2 & 12 & Medical Centers & 2.2 & 12 & Jersey branding & 2.7 & 13 \\
\hline TOTAL SCORE & 44 & & TOTAL SCORE & 44.1 & & TOTAL SCORE & 49.9 & \\
\hline $\begin{array}{l}\text { TOTAL MEAN } \\
\text { SCORE }\end{array}$ & 3.38 & & $\begin{array}{l}\text { TOTAL MEAN } \\
\text { SCORE }\end{array}$ & 3.38 & & $\begin{array}{l}\text { TOTAL MEAN } \\
\text { SCORE }\end{array}$ & 3.84 & \\
\hline $\begin{array}{c}\% \\
\text { PERFORMANCE }\end{array}$ & 68 & & $\begin{array}{c}\% \\
\text { PERFORMANCE }\end{array}$ & 68 & & $\begin{array}{c}\% \\
\text { PERFORMANCE }\end{array}$ & 77 & \\
\hline
\end{tabular}


Table 5. Cash flow regularity measure $\left(\mathrm{F}_{1}\right)$ (continued)

\begin{tabular}{|c|c|c|c|c|c|c|c|c|}
\hline $\begin{array}{l}\text { LEKAN SALAMI } \\
\text { STADIUM }\end{array}$ & Mean & Rank & $\begin{array}{l}\text { LIBERTY } \\
\text { STADIUM }\end{array}$ & Mean & Rank & $\begin{array}{l}\text { OLUBADAN } \\
\text { STADIUM }\end{array}$ & Mean & Rank \\
\hline Sales ticket & 4.2 & 1 & Sales ticket & 4.8 & 1 & Adverts & 4.1 & 1 \\
\hline T.V rights & 4.1 & 2 & T.V rights & 4.6 & 2 & Sales ticket & 4.1 & 1 \\
\hline Rent & 4.1 & 2 & School support & 4.5 & 3 & Rent & 4 & 3 \\
\hline School support & 4 & 4 & Rent & 4.5 & 3 & T.V rights & 3.9 & 4 \\
\hline $\begin{array}{l}\text { Corporate } \\
\text { responsibility }\end{array}$ & 4 & 4 & $\begin{array}{l}\text { Corporate } \\
\text { responsibility }\end{array}$ & 4.4 & 5 & $\begin{array}{l}\text { Corporate } \\
\text { responsibility }\end{array}$ & 3.9 & 4 \\
\hline Adverts & 3.9 & 6 & Adverts & 4.2 & 6 & $\begin{array}{l}\text { Internal Generated } \\
\text { Revenue (IGR) }\end{array}$ & 3.8 & 6 \\
\hline $\begin{array}{l}\text { Internal Generated } \\
\text { Revenue (IGR) }\end{array}$ & 3.8 & 7 & $\begin{array}{l}\text { Internal Generated } \\
\text { Revenue (IGR) }\end{array}$ & 4.2 & 6 & $\begin{array}{l}\text { Annual budget } \\
\text { disbursement }\end{array}$ & 3.5 & 7 \\
\hline $\begin{array}{l}\text { Annua budget } \\
\text { disbursement }\end{array}$ & 3.6 & 8 & $\begin{array}{l}\text { Annual budget } \\
\text { disbursement }\end{array}$ & 4.1 & 8 & Corporate suites & 3.1 & 8 \\
\hline Corporate suites & 3.2 & 9 & Corporate suites & 3.8 & 9 & School support & 2.8 & 9 \\
\hline Restaurants/kiosks & 2.8 & 10 & Medical Centers & 3.2 & 10 & Restaurants/kiosks & 2.8 & 9 \\
\hline Sales souvenirs' & 2.8 & 10 & Restaurants/kiosks & 3.2 & 10 & Sales souvenirs' & 2.8 & 9 \\
\hline Jersey branding & 2.3 & 12 & Sales souvenirs' & 3.2 & 10 & Jersey branding & 2.2 & 12 \\
\hline Medical Centers & 2.3 & 12 & Jersey branding & 3 & 13 & Medical Centers & 2.2 & 12 \\
\hline TOTAL SCORE & 45.1 & & TOTAL SCORE & 51.7 & & TOTAL SCORE & 43.2 & \\
\hline $\begin{array}{l}\text { TOTAL MEAN } \\
\text { SCORE }\end{array}$ & 3.47 & & $\begin{array}{l}\text { TOTAL MEAN } \\
\text { SCORE }\end{array}$ & 3.98 & & $\begin{array}{l}\text { TOTAL MEAN } \\
\text { SCORE }\end{array}$ & 3.24 & \\
\hline $\begin{array}{c}\% \\
\text { PERFORMANCE }\end{array}$ & 69 & & $\begin{array}{c}\% \\
\text { PERFORMANCE }\end{array}$ & 80 & & $\begin{array}{c}\% \\
\text { PERFORMANCE }\end{array}$ & 66 & \\
\hline
\end{tabular}

Table 6. Cash flow rating $\left(\mathrm{F}_{2}\right)$

\begin{tabular}{|c|c|c|c|c|c|c|c|c|}
\hline AKURE STADIUM & Mean & Rank & $\begin{array}{l}\text { OSHOGBO } \\
\text { STADIUM }\end{array}$ & Mean & Rank & ONDO STADIUM & Mean & Rank \\
\hline T.V rights & 3.6 & 1 & Sales ticket & 3.8 & 1 & Restaurants/kiosks & 3.9 & 1 \\
\hline Adverts & 3.2 & 2 & $\begin{array}{l}\text { Corporate } \\
\text { responsibility }\end{array}$ & 3.8 & 1 & Sales souvenirs & 3.7 & 2 \\
\hline Sales ticket & 3 & 3 & $\begin{array}{l}\text { Eternal Generated } \\
\text { Revenue (IGR) }\end{array}$ & 3.6 & 3 & T.V rights & 3.6 & 3 \\
\hline $\begin{array}{l}\text { Corporate } \\
\text { responsibility }\end{array}$ & 2.9 & 4 & T.V rights & 3.4 & 4 & Sales ticket & 3.5 & 4 \\
\hline Rent & 2.8 & 5 & Adverts & 3 & 5 & Adverts & 3.4 & 5 \\
\hline Corporate suites & 2.8 & 5 & Corporate suites & 3 & 5 & $\begin{array}{l}\text { Corporate } \\
\text { responsibility }\end{array}$ & 3.4 & 5 \\
\hline $\begin{array}{l}\text { Internal Generated } \\
\text { Revenue (IGR) }\end{array}$ & 2.8 & 5 & Rent & 2.8 & 7 & $\begin{array}{l}\text { Internal Generated } \\
\text { Revenue (IGR) }\end{array}$ & 3.3 & 7 \\
\hline $\begin{array}{l}\text { Annual budget } \\
\text { disbursement }\end{array}$ & 2.8 & 5 & $\begin{array}{l}\text { Annual budget } \\
\text { disbursement }\end{array}$ & 2.8 & 7 & $\begin{array}{l}\text { Annual budget } \\
\text { Disbursement }\end{array}$ & 3.3 & 7 \\
\hline School support & 2.2 & 9 & Restaurants/kiosks & 2.7 & 9 & School support & 3.1 & 9 \\
\hline Restaurants/kiosks & 2 & 10 & Sales souvenirs & 2.6 & 10 & Corporate suites & 2.9 & 10 \\
\hline Sales souvenirs & 2 & 10 & School support & 2.2 & 11 & Rent & 2.8 & 11 \\
\hline Jersey branding & 1.8 & 12 & Jersey branding & 2 & 12 & Jersey branding & 2.6 & 12 \\
\hline Medical Centers & 1.8 & 12 & Medical Centers & 2 & 12 & Medical Centers & 2.6 & 12 \\
\hline TOTAL SCORE & 33.7 & & TOTAL SCORE & 37.7 & & TOTAL SCORE & 42.1 & \\
\hline $\begin{array}{l}\text { TOTAL MEAN } \\
\text { SCORE }\end{array}$ & 2.6 & & $\begin{array}{l}\text { TOTAL MEAN } \\
\text { SCORE }\end{array}$ & 2.9 & & $\begin{array}{l}\text { TOTA MEAN } \\
\text { SCORE }\end{array}$ & 3.24 & \\
\hline$\%$ PERFORMANCE & 52 & & $\%$ PERFORMANCE & 58 & & $\%$ PERFORMANCE & 64 & \\
\hline
\end{tabular}


Table 6. Cash flow rating $\left(\mathrm{F}_{2}\right)$ (continued)

\begin{tabular}{|c|c|c|c|c|c|c|c|c|}
\hline $\begin{array}{l}\text { LEKAN SALAMI } \\
\text { STADIUM }\end{array}$ & Mean & Rank & $\begin{array}{l}\text { LIBERTY } \\
\text { STADIUM }\end{array}$ & Mean & Rank & $\begin{array}{l}\text { OLUBADAN } \\
\text { STADIUM }\end{array}$ & Mean & Rank \\
\hline T.V rights & 3.6 & 1 & $\begin{array}{c}\text { Annual budget } \\
\text { disbursement }\end{array}$ & 4.6 & 1 & $\begin{array}{c}\text { Corporate } \\
\text { responsibility }\end{array}$ & 4.1 & 1 \\
\hline $\begin{array}{l}\text { Internal Generated } \\
\text { Revenue (IGR) }\end{array}$ & 3.6 & 1 & Adverts & 3.8 & 2 & $\begin{array}{l}\text { Internal Generated } \\
\text { Revenue (IGR) }\end{array}$ & 3.9 & 2 \\
\hline Adverts & 3.4 & 3 & T.V rights & 3.8 & 2 & T.V rights & 3.6 & 3 \\
\hline $\begin{array}{l}\text { Annual budget } \\
\text { disbursement }\end{array}$ & 3.4 & 3 & Restaurants/kiosks & 3.8 & 2 & Adverts & 3.2 & 4 \\
\hline Jersey branding & 3 & 5 & School support & 3.4 & 5 & Rent & 2.8 & 5 \\
\hline Sales ticket & 3 & 5 & Rent & 3.4 & 5 & Corporate suites & 2.8 & 5 \\
\hline Rent & 2.9 & 7 & Sales ticket & 3.3 & 7 & Sales souvenirs & 2.8 & 5 \\
\hline $\begin{array}{l}\text { Corporate } \\
\text { responsibility }\end{array}$ & 2.9 & 7 & $\begin{array}{l}\text { Corporate } \\
\text { responsibility }\end{array}$ & 3.2 & 8 & Sales ticket & 2.8 & 5 \\
\hline Corporate suites & 2.8 & 9 & $\begin{array}{l}\text { Internal Generated } \\
\text { Revenue (IGR) }\end{array}$ & 3.2 & 8 & $\begin{array}{l}\text { Annual budget } \\
\text { disbursement }\end{array}$ & 2.8 & 5 \\
\hline Medical Centers & 2.6 & 10 & Corporate suites & 2.9 & 10 & School support & 2.2 & 10 \\
\hline School support & 2.4 & 11 & Sales souvenirs & 2.9 & 10 & Restaurants/kiosks & 2 & 11 \\
\hline Restaurants/kiosks & 2.2 & 12 & Jersey branding & 1.9 & 12 & Jersey branding & 1.8 & 12 \\
\hline Sales souvenirs & 2.2 & 12 & Medical Centers & 1.9 & 12 & Medical Centers & 1.8 & 12 \\
\hline TOTAL SCORE & 38 & & TOTAL SCORE & 42.1 & & TOTAL SCORE & 36.6 & \\
\hline $\begin{array}{l}\text { TOTAL MEAN } \\
\text { SCORE }\end{array}$ & 2.92 & & $\begin{array}{l}\text { TOTAL MEAN } \\
\text { SCORE }\end{array}$ & 3.24 & & $\begin{array}{l}\text { TOTAL MEAN } \\
\text { SCORE }\end{array}$ & 2.81 & \\
\hline $\begin{array}{c}\% \\
\text { PERFORMANCE }\end{array}$ & 58 & & $\begin{array}{c}\% \\
\text { PERFORMANCE }\end{array}$ & 65 & & $\begin{array}{c}\% \\
\text { PERFORMANCE }\end{array}$ & 56 & \\
\hline
\end{tabular}

Table 7. Facility maintenance cost reduction measure $\left(\mathrm{F}_{3}\right)$

\begin{tabular}{|c|c|c|c|c|c|c|c|c|}
\hline AKURE STADIUM & Mean & Rank & $\begin{array}{l}\text { OSHOGBO } \\
\text { STADIUM }\end{array}$ & Mean & Rank & ONDO STADIUM & Mean & Rank \\
\hline Asset management & 4.1 & 1 & Asset management & 4.4 & 1 & Asset management & 4.5 & 1 \\
\hline $\begin{array}{l}\text { Management of } \\
\text { Working capital } \\
\text { reduction on the } \\
\text { administrati ve cost }\end{array}$ & 3.9 & 2 & $\begin{array}{l}\text { Management of } \\
\text { working capital } \\
\text { reduction on the } \\
\text { administrative cost }\end{array}$ & 4 & 2 & $\begin{array}{l}\text { Management of } \\
\text { Working capital } \\
\text { reduction on the } \\
\text { administrative cost }\end{array}$ & 4 & 2 \\
\hline $\begin{array}{l}\text { Productivity with cost } \\
\text { reduction }\end{array}$ & 3.9 & 2 & $\begin{array}{l}\text { Productivity with } \\
\text { cost reduction }\end{array}$ & 4 & 2 & $\begin{array}{l}\text { Productivity with } \\
\text { cost reduction }\end{array}$ & 4 & 2 \\
\hline TOTAL SCORE & 11.9 & & TOTAL SCORE & 12.4 & & TOTAL SCORE & 12.5 & \\
\hline $\begin{array}{l}\text { TOTAL MEAN } \\
\text { SCORE }\end{array}$ & 3.97 & & $\begin{array}{l}\text { TOTAL MEAN } \\
\text { SCORE }\end{array}$ & 4.13 & & $\begin{array}{l}\text { TOTA MEAN } \\
\text { SCORE }\end{array}$ & 4.167 & \\
\hline$\%$ PERFORMANCE & 79 & & $\%$ PERFORMANCE & 83 & & $\%$ PERFORMANCE & 83 & \\
\hline
\end{tabular}

Table 7. Facility maintenance cost reduction measure $\left(\mathrm{F}_{3}\right)$ (continued)

\begin{tabular}{|c|c|c|c|c|c|c|c|c|}
\hline $\begin{array}{l}\text { LEKAN SALAMI } \\
\text { STADIUM }\end{array}$ & Mean & Rank & $\begin{array}{l}\text { LIBERTY } \\
\text { STADIUM }\end{array}$ & Mean & Rank & $\begin{array}{l}\text { OLUBADAN } \\
\text { STADIUM }\end{array}$ & Mean & Rank \\
\hline Asset management & 4.2 & 1 & Asset management & 4.8 & 1 & Asset management & 4.1 & 1 \\
\hline $\begin{array}{l}\text { Management of } \\
\text { Working capital } \\
\text { reduction on the } \\
\text { administrative cost }\end{array}$ & 3.9 & 2 & $\begin{array}{l}\text { Management of } \\
\text { working capital } \\
\text { reduction on the } \\
\text { administrative cost }\end{array}$ & 4 & 2 & $\begin{array}{l}\text { Management of } \\
\text { working capital } \\
\text { reduction on the } \\
\text { administrative cost }\end{array}$ & 3.9 & 2 \\
\hline $\begin{array}{l}\text { Productivity with cost } \\
\text { reduction }\end{array}$ & 3.9 & 2 & $\begin{array}{l}\text { Productivity with } \\
\text { cost reduction }\end{array}$ & 4 & 2 & $\begin{array}{l}\text { Productivity with } \\
\text { cost reduction }\end{array}$ & 3.9 & 2 \\
\hline TOTAL SCORE & 12 & & TOTAL SCORE & 12.8 & & TOTAL SCORE & 11.9 & \\
\hline $\begin{array}{l}\text { TOTAL MEAN } \\
\text { SCORE }\end{array}$ & 4 & & $\begin{array}{l}\text { TOTAL MEAN } \\
\text { SCORE }\end{array}$ & 4.27 & & $\begin{array}{l}\text { TOTA MEAN } \\
\text { SCORE }\end{array}$ & 3.97 & \\
\hline$\%$ PERFORMANCE & 80 & & $\%$ PERFORMANCE & 85 & & $\%$ PERFORMANCE & 79.33 & \\
\hline
\end{tabular}


Table 8. Summary of total performance ratings of the stadia

\begin{tabular}{ccccccc}
\hline & AKURE & OSHOGBO & ONDO & LEKAN SALAMI & LIBERTY & OLUBADAN \\
& STADIUM & STADIUM & STADIUM & STADIUM & STADIUM & STADIUM \\
\hline $\mathrm{N}$ & 3.14 & 3.31 & 3.35 & 3.11 & 3.55 & 3.17 \\
$\%$ & 63 & 67 & 67 & 62 & 71 & 63 \\
\hline
\end{tabular}

